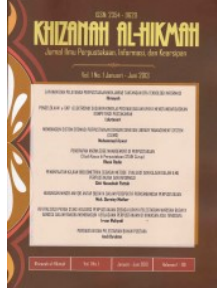

\title{
ANALISIS BIBLIOMETRIK ILMU DAN TEKNOLOGI PANGAN: PUBLIKASI ILMIAH DI NEGARA-NEGARA ASEAN
}

\author{
Tupan*, Rulina Rachmawati*
}

Pengutipan: Tupan., dan Rachmawati, R. (2018). Analisis bibliometric ilmu dan teknologi pangan: publikasi ilmiah di Negara-Negara ASEAN. Khizanah al-Hikmah : Jurnal Ilmu Perpustakaan, Informasi, dan Kearsipan, 6(1), 26-40.

DOI: $10.24252 /$ kah.v6a1a4

\author{
*PDII-LIPI \\ tupan712190@gmail.com
}

\section{ABSTRAK}

Dilakukan kajian untuk mengetahui (1) pertumbuhan jumlah publikasi ilmiah bidang ilmu dan teknologi pangan, (2) jurnal inti (core jurnal), (3) produktivitas peneliti; (4) jumlah dokumen berdasarkan kolaborasi lembaga; (5) jumlah publikasi berdasarkan subjek/bidang; (6) peta perkembangan publikasi berdasarkan kata kunci dan pengarang pada negara-negara ASEAN. Penelitian menggunakan metode bibliometrik. Pengumpulan data dengan cara melakukan penelusuran melalui database scopus dengan kata kunci Food science and technology dengan katagori Article title, Abstract, Keywords dalam kurun waktu 1996-2016. Data dianalisis berdasarkan tahun, penulis, asal penulis dan subjek menggunakan Microsoft Excel 2010. Sedangkan untuk peta perkembangan publikasi dianalisis dengan menggunakan software VosViewer. Hasil kajian menunjukkan bahwa pertumbuhan publikasi ilmiah ilmu dan teknologi pangan negara-negara ASEAN menunjukkan adanya kenaikan dan pertumbuhan tertinggi terjadi di tahun 2013 yaitu sebanyak 113 dokumen (14,71\%). Publikasi terbanyak dipublikasikan pada jurnal inti International Journal Of Food Science And Technology yaitu sebanyak 240 publikasi. Lembaga penyumbang publikasi tertinggi adalah Universiti Putra Malaysia sebanyak 95 publikasi. Peneliti paling produktif dari negara Thailand diantaranya Benjakul, S., Benjakul, S., Noomhorm, A, Therdthai, N., Devahastin, S. Negara yang paling produktif adalah Thailand sebanyak 310 publikasi. Subjek yang terbanyak adalah Agricultural and Biological Sciences sebanyak 620 dokumen (80,7\%), disusul Engineering sebanyak $318(41,4 \%)$, Biochemistry, Genetics and Molecular Biology sebanyak 112 dokumen $(14,6 \%)$, Immunology and Microbiology 74 dokumen $(9,6 \%)$ dan tertinggi dalam bentuk artikel. Melalui visualisai network terlihat hubungan antartopik mengelompok menjadi 7 kluster

Kata kunci: Bibliometrika; ilmu dan teknologi pangan; ASEAN

\section{ABSTRACT}

The study was conducted to find out (1) the growth of scientific publications in food science and technology; (2) core journals; (3) productivity; (4) the number of documents based on agency collaboration; (5) the number of publications based on subject / field; (6) the mapping of scientific publication in food science and technology based on keywords and authors in ASEAN countries. This study used bibliometric method. Data was collected by searching through Scopus database by using Food science and technology as keyword on the article title, abstract, keywords category for the period of 1996-2016. Data was analyzed by year, authors, author and subject using Microsoft Excel 2010. The mapping of scientific publication was analyzed using VosViewer software. The result showed that the growth of scientific publication of food science and technology of ASEAN countries experienced the highest increase and growth in 2013 (113 documents or 14.71\%). Scientific publications of food science and technology of most ASEAN countries were published in the Journal of International Food Science And Technology (240 publications). The highest contributor was Universiti Putra Malaysia with 95 publications. The most prolific researchers were from Thailand, among them Benjakul, S., Benjakul, S., Noomhorm, A, Therdthai, N., Devahastin, S. The most productive countries was Thailand (310 publications). The highest number of scientific publications of ASEAN countries are Agricultural and Biological Sciences (620 documents or 80.7\%), followed by Engineering 
(318 or 41.4\%), Biochemistry, Genetics and Molecular Biology had as many as 112 documents or 14.6\%, Immunology and Microbiology (74 documents or 9.6\%) and most of them were journal articles. Through network visualization, it was showed that the topic relationships are grouped into 7 clusters.

Keywords: Bibliometrics; food and science technology; ASEAN

\section{PENDAHULUAN}

\section{a. Latar Belakang}

ASEAN (Association of South East Asian Nations) merupakan organisasi kerjasama bidang geo-politik dan ekonomi di antara negara-negara Asia Tenggara, di mana saat ini anggotanya terdiri dari sepuluh negara antara lain Indonesia, Singapura, Malaysia, Thailand, Vietnam, Kamboja, Laos, Filipina, Brunei Darussalam, dan Myanmar. Pertumbuhan ekonomi negara-negara anggota ASEAN yang cepat menjadikan wilayah ASEAN sebagai kekuatan ekonomi Asia dan membuka peluang kerjasama pertukaran ilmu pengetahuan, inovasi, dan teknologi.

Salah satu agenda kerjasama ASEAN dalam peningkatan pertumbuhan ekonomi regional dan ketahanan wilayah dilakukan melalui kerjasama di bidang penelitian ilmu pengetahuan $\mathrm{M}$ dan teknologi, yaitu teknologi pangan. Ilmu dan teknologi pangan sangat berperan penting dalam menjaga ketahanan pangan suatu negara.

Kerjasama penelitian antar negara dapat diketahui melalui kolaborasi dalam penulisan publikasi ilmiah (Kumar, 2014). Kolaborasi internasional biasanya dilakukan antara negara sedang berkembang dengan negara berkembang atau negara maju. Beberapa faktor yang mempengaruhi kolaborasi internasional antara lain faktor kognitif, sosial, dan budaya seperti kedekatan geografis, kesamaan bahasa, perkembangan sejarah, dan sistem pendidikan nasional (Haustein et al, 2011).

Metode bibliometrik telah digunakan untuk mengetahui tingkat kolaborasi dan produktivitas penelitian negara-negara ASEAN. U1 Hassan et al. (2012) melakukan penelitian untuk menggambarkan kekuatan penelitian negara-negara ASEAN yaitu jumlah dan fokus dalam bidang ilmu pengetahuan dan teknologi, serta kolaborasi antara negara-negara ASEAN dengan negaranegara Uni Eropa. Payumo dan Sutton (2015) melakukan penelitian bibliometrik mengenai kolaborasi negara-negara ASEAN di bidang bioteknologi tumbuhan. Kumar et al. (2014) melakukan kajian terhadap performa penelitian dan kolaborasi penelitian internasional negara-negara ASEAN dalam bidang ekonomi. Sombatsompop et al. (2011) mengkaji produktivitas penelitian dan dampak penelitian negara anggota ASEAN dalam bidang energi dan bahan bakar.

Penelitian mengenai kolaborasi negara-negara ASEAN di bidang ilmu dan teknologi pangan belum dilakukan. Oleh karena itu, dalam kajian ini metode bibliometrik digunakan untuk mengkaji pertumbuhan publikasi ilmiah ilmu dan teknologi pangan di negara-negara ASEAN berdasarkan afiliasi/lembaga, negara, subjek; pertumbuhan jurnal inti; tingkat produktivitas peneliti; serta memetakan perkembangan penelitian berdasakan kata kunci. 


\section{b. Rumusan Masalah}

Penelitian ini akan menjawab permasalahan sebagai berikut:

1) Bagaimanakah jumlah pertumbuhan publikasi ilmiah ilmu dan teknologi pangan di negera negara ASEAN?

2) Bagaimana pertumbuhan jurnal inti yang mempublikasikan publikasi ilmiah ilmu dan teknologi pangan?

3) Bagaimana pertumbuhan jumlah publikasi ilmiah negara-negara ASEAN berdasrakan afiliasi/lembaga?

4) Bagaimana tingkat produktivitas peneliti ilmu dan teknologi pangan negara-negara ASEAN ?

5) Bagaimana pertumbuhan jumlah dokumen publikasi ilmiah terindek scopus berdasarkan negara?

6) Bagaimana pertumbuhan jumlah dokumen publikasi ilmiah ilmu dan teknologi pangan negara-negara ASEAN berdasarkan subjek?

7) Bagaimana peta perkembangan publikasi ilmiah negara-negara ASEAN berdasarkan kata kunci dan pengarang?

\section{c. Tujuan Penelitian}

Tujuan penelitian ini adalah untuk mengetahui:

1) Pertumbuhan jumlah publikasi ilmiah ilmu dan teknologi pangan negaranegara ASEAN pada database scopus dari tahun 1996 -2016,

2) Jurnal inti (core jurnal) dalam publikasi ilmiah ilmudan teknologi pangan negara-negara ASEAN,

3) Pertumbuhan jumlah publikasi ilmiah Negara-negara ASEAN berdasarkan afiliasi/lembaga,
4) Produktivitas peneliti ilmu dan teknologi pangan negara-negara ASEAN,

5) Jumlah dokumen berdasarkan kolaborasi lembaga dalam publikasi ilmiah ilmu dan teknologi pangan negara-negara ASEAN,

6) Jumlah publikasi ilmiah ilmu dan teknologi pangan berdasarkan subjek/bidang, dan

7) Peta perkembangan publikasi ilmiah ilmu dan teknologi pangan berdasarkan kata kunci dan pengarang.

\section{TINJAUAN LITERATUR}

\section{a. Produktivitas Ilmiah}

Produktivitas ilmiah ditentukan berdasarkan keluaran aktivitas ilmiah. Keluaran tersebut dapat berupa publikasi artikel ilmiah dan bentuk lainnya, prototipe dan artifak fisik lainnya, teori dan konten, dan kualitas sumber daya manusia maupun institusi yang lebih baik. Penentuan produktivitas ilmiah memerlukan usaha ekstra dan tidak semua keluaran dapat diukur, dalam beberapa kasus informasi tersebut tidak dapat diakses. Oleh karena itu, dalam banyak penelitian menggunakan pendekatan scientometric, jumlah artikel yang dipublikasikan dalam jurnal peerreviewed digunakan sebagai acuan produktivitas ilmiah.

Produktivitas ilmiah dipengaruhi oleh beberapa faktor, yaitu faktor yang berkaitan dengan pendanaan dan faktor non pendanaan. Produktivitas ilmiah dipengaruhi secara langsung oleh besar kecilnya pendanaan yang disediakan untuk aktivitas penelitian ilmiah. Produktivitas ilmiah individu juga dipengaruhi oleh faktor non pendanaan seperti faktor institusi atau sosial (ikatan 
secara sosial dengan senior atau komitmen untuk bekerja sama dengan senior) (Lakitan dkk., 2012).

\section{b. Kolaborasi Penelitian}

\section{Kolaborasi atau collaboration} mempunyai arti kerjasama. Kolaborasi mencakup semua kegiatan yang ingin dicapai dan mempunyai tujuan serta manfaat bersama. Kegiatan kolaborasi dalam penelitian secara umum dapat dilihat dalam kegiatan penulisan suatu karya yang melibatkan banyak penulis (Wulan, 2014).

Kolaborasi penelitian dapat dilakukan dalam berbagai level seperti individu, kelompok ahli, institusi, dan negara. Kolaborasi antara institusi riset, industri, dan pemerintah dikenal sebagai "triple helix". Di level individu, keuntungan dari melakukan kolaborasi antara lain meningkatkan pengetahuan, meningkatkan kualitas penelitian, meningkatkan hubungan dan kerja sama di masa depan, dan menghasilkan ide-ide baru. Kolaborasi di level institusi memiliki berbagai format dan ukuran, bilateral atau multilateral, dalam satu bidang atau berbagai bidang ilmu pengetahuan. Berbagai jenis kolaborasi ini harus menguntungkan semua pihak yang terlibat.

\section{Alasan utama dilakukannya} kolaborasi antara individu antara lain berbagi keahlian, berbagi peralatan atau sumber daya yang tidak dimiliki oleh salah satu pihak, meningkatkan akses terhadap pendanaan, mendapatkan prestige, mempelajari pengetahuan baru mengenai teknik, permasalahan yang lebih kompleks, meningkatkan produktivitas ilmiah, dan meningkatkan spesialisasi ilmu pengetahuan. Bagi institusi, pemerintahan, atau badan pemberi dana penelitian, kolaborasi penelitian bertujuan untuk meningkatkan efisiensi pendanaan, meminimalisir pengulangan aktivitas penelitian yang tidak perlu, memaksimal pertukaran pengetahuan (Lakitan dkk., 2012).

Kolaborasi antarnegara atau kolaborasi internasional dilakukan dengan alasan utama untuk berbagi biaya penelitian. Oleh karena itu, kolaborasi internasional biasanya dilakukan antara negara sedang berkembang dengan negara berkembang atau negara maju. Beberapa faktor yang mempengaruhi kolaborasi internasional antara lain faktor kognitif, sosial, dan budaya seperti kedekatan geografis, kesamaan bahasa, perkembangan sejarah, dan sistem pendidikan nasional (Haustein et al, 2011).

\section{c. Bibliometrika}

Bibliometrika merupakan bidang kajian yang dapat mengungkapkan besaran dan keunggulan suatu bidang ilmu tertentu bahkan suatu lembaga pendidikan tertentu dengan penerapan berbagai teori di dalamnya seperti analisis kepengarangan, analisis sitiran, webometrik (bibliometrik berbasis web), kerjasama kepengarangan, keusangan dokumen, faktor dampak, dan sebagainya. Dengan pemanfaatan biblimetrika dapat diketahui bagaimana produktifitas dan sebaran atau distribusi publikasi ilmiah tersebut dalam bidang keilmuannya. Kajian bibliometrika juga dapat memberikan pemahaman yang lebih luas terhadap keseluruhan disiplindidiplin ilmu, mengungkapkan namanama pengarang yang paling produktif dalam suatu disiplin ilmu, negara, bahasa yang lebih banyak digunakan dalam suatu bidang ilmu (Nuryudi, 2016). 


\section{d. Penelitian Terdahulu}

Ul Hassan et al. (2012) melakukan penelitian mengenai aktivitas penelitian negara-negara ASEAN dan hubungannya terhadap bidang prioritas FP7 Uni Eropa dengan pendekatan bibliometrik. Bibliometrik digunakan untuk menggambarkan kekuatan penelitian negara-negara ASEAN yaitu jumlah dan fokus dalam bidang ilmu pengetahuan dan teknologi, serta kolaborasi antara negara-negara ASEAN dengan negaranegara Uni Eropa. Hasil penelitian menunjukkan bahwa sitasi hasil penelitian ASEAN terhadap bidang prioritas Uni Eropa relatif kurang, nanoteknologi adalah satu-satunya bidang dimana ASEAN berkolaborasi dengan Uni Eropa.

Payumo dan Sutton (2015) melakukan penelitian bibliometrik mengenai kolaborasi negara-negara ASEAN di bidang bioteknologi tumbuhan. Data publikasi dan sitiran bidang bioteknologi tumbuhan dalam periode sepuluh tahun dianalisis untuk mengetahui performa penelitian, dampak, dan kolaborasi diantara negara-negara anggota ASEAN. Secara umum, hasil penelitian menunjukkan bahwa keluaran ilmiah bidang bioteknologi tumbuhan meningkat dari waktu ke waktu. Performa penelitian dan kolaborasi (domestik, regional, dan internasional) berkaitan dengan status pertumbuhan ekonomi setiap negara anggota. Thailand menghasilkan publikasi paling banyak, sementara Singapura mempunyai pengaruh tertinggi yang diindikasikan dengan banyaknya artikel yang disitir diantara negara anggota ASEAN lainnya.

Kumar et al. (2014) melakukan kajian terhadap performa penelitian dan kolaborasi penelitian internasional negara-negara ASEAN dalam bidang ekonomi. Hasil penelitian menunjukkan bahwa dalam tiga dekade terakhir, tulisan dengan kolaborasi internasional mengalami peningkatan dibandingkan kolaborasi lokal. Singapura menunjukkan performa penelitian terbaik diantara negara-negara anggota dikarenakan wilayah geografis, populasi, dan GDP. Kolaborasi diantara negara-negara ASEAN masih relatif rendah. Amerika serikat menjadi patner kolaborasi internasional yang paling diminati oleh seluruh negara anggota ASEAN.

Sombatsompop et al. (2011) mengkaji performa penelitian yaitu produktivitas penelitian dan dampak penelitian negara anggota ASEAN dalam bidang energi dan bahan bakar menggunakan pendekatan bibliometrik. Hasil penelitian menunjukkan bahwa Thailand menghasilkan publikasi artikel tertinggi sedangkan Singapura tertinggi dalam total sitiran dan sitiran per publikasi. Singapura menunjukkan performa penelitian diatas negara-negara ASEAN lainnya.

\section{METODOLOGI PENELITIAN}

\section{a. Kerangka Pikir}

Analisis bibliometrik merupakan satu kajian analisis bibliografi pada kegiatan ilmiah, yang berbasiskan pada asumsi bahwa seorang peneliti melaksanakan atau melakukan penelitiannya dan harus mengkomunikasikan hasilnya pada teman sejawat. Hasil analisis bibliometrik dapat divisualisasikan menggunakan beberapa program komputer seperti Vosviewer, Pajek, Gephi. Vosviewer merupakan program komputer yang tersedia secara gratis untuk, memvisualisasikan, dan mengeksplor peta pengetahuan 
bibliometrik http://www.vosviewer.com, (Leydesdorff dan Rafols, 2012).

Algoritma yang digunakan dalam program ini adalah MDS (Multi Dimentional Scalling). Kluster yang dihasilkan melalui VOSviewer secara otomatis ditampilkan berwarna dalam peta. Berdasarkan uraian tersebut di atas maka kerangka pikir kajian disajikan pada Gambar 1.

\section{d. Teknik Analisis data}

Data berupa jumlah publikasi ilmiah ilmu dan teknologi dianalisis berdasarakan tahun, penulis, asal penulis dan subjek dianalisis menggunakan Microsoft Excel 2010. Sedangkan untuk peta perkembangan publikasi ilmiah ilmu dan teknologi pangan negara-negara ASEAN dianalisis dengan menggunakan software Vosviewer.

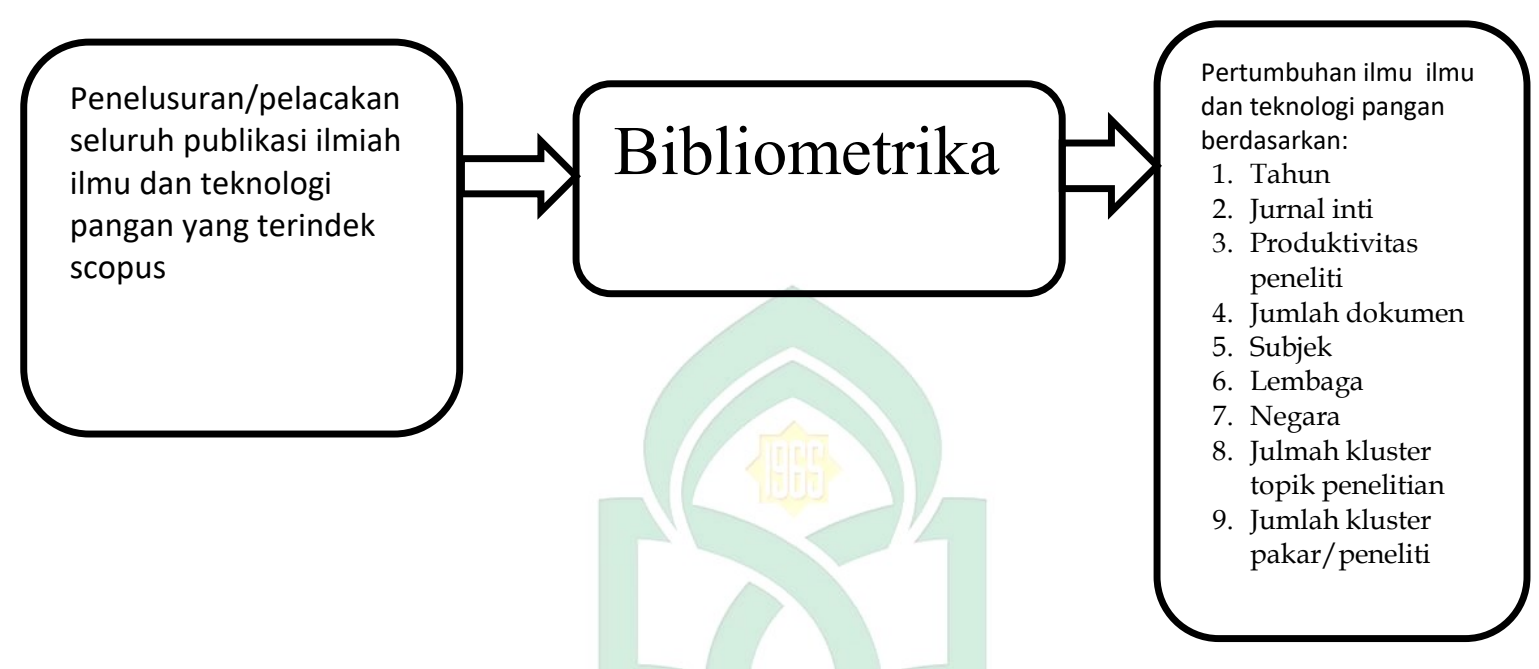

Gambar 1. Kerangka pikir

\section{b. Populasi}

Populasi penelitian adalah publikasi ilmiah ilmu dan teknologi pangan negaranegara ASEAN yang terindek scopus selama periode 20 tahun (1996-2016). Jumlah populasi yang dimaksud adalah sebanyak 768 judul publikasi ilmiah (12 Januari 2018).

\section{c. Teknik Pengumpulan Data}

Pengumpulan data dengan cara melakukan penelusuran melalui database scopus dengan kata kunci Food science and technology dengan katagori Article title, Abstract, Keywords dalam kurun waktu 1996-2016.

\section{HASIL PENELITIAN DAN PEMBAHASAN}

Pada bagian ini dibahas pertumbuhan publikasi ilmiah ilmu dan teknologi pangan negara- negara ASEAN berdasarkan tahun, jurnal inti (core journal) dalam publikasi ilmiah ilmu dan teknologi pangan, jumlah publikasi ilmiah ilmu dan teknologi pangan berdasarkan lembaga/afiliasi, produktivitas peneliti ilmu dan teknologi pangan negara-negara ASEAN, jumlah publikasi ilmiah ilmu dan teknologi pangan berdasarkan negara, jumlah publikasi ilmiah ilmu dan teknologi pangan berdasarkan subjek dan tipe dokumen. Selain itu, pada bagian ini juga dilengkapi dengan peta 
pertumbuhan publikasi ilmiah ilmu dan teknologi pangan berdasarkan kata kunci.

\section{a. Pertumbuhan Publikasi Ilmiah Ilmu dan Teknologi Pangan Berdasarkan Tahun}

Pertumbuhan publikasi ilmiah ilmu dan teknologi pangan selama periode 1996-2016 mengalami peningkatan yang signifikan. Pertumbuhan publikasi ilmiah ilmu dan teknologi pangan negara-negara ASEAN yang terindek di Scopus tertinggi terjadi pada tahun 2013 yang mencapai 113 dokumen (14,71). Selengkapnya pertumbuhan publikasi ilmiah ilmu dan teknologi pangan dapat dilihat pada Tabel 1 berikut.

Tabel 1. Pertumbuhan publikasi ilmiah ilmu dan teknologi pangan berdasarkan tahun

\begin{tabular}{l|l|l}
\hline $\begin{array}{c}\text { Tahun } \\
\text { Publikasi }\end{array}$ & Jumlah & Persentase \\
\hline 2016 & 80 & 10,41 \\
\hline 2015 & 81 & 10,54 \\
\hline 2014 & 104 & 13,54 \\
\hline 2013 & 113 & 14,71 \\
\hline 2012 & 88 & 11,46 \\
\hline 2011 & 84 & 10,94 \\
\hline 2010 & 33 & 4,29 \\
\hline 2009 & 37 & 4,82 \\
\hline 2008 & 51 & 6,64 \\
\hline 2007 & 34 & 4,43 \\
\hline 2006 & 12 & 1,56 \\
\hline 2005 & 16 & 2,08 \\
\hline 2004 & 6 & 0,78 \\
\hline 2003 & 6 & 0,78 \\
\hline 2002 & 8 & 1,04 \\
\hline 2001 & 8 & 1,04 \\
\hline 2000 & 5 & 0,65 \\
\hline 1999 & 2 & 0,26 \\
\hline 1998 & 0 & 0 \\
\hline 1997 & 0 & 0 \\
\hline 1996 & 0 & 0 \\
\hline Jumlah & 768 & 100 \\
\hline & &
\end{tabular}

Pertumbuhan publikasi ilmiah ilmu dan teknologi pangan negara-negara
ASEAN berdasarkan Tabel 1 dan Gambar 2 menunjukkan bahwa selama periode tahun 1996-2016 mengalami kenaikan dan pertumbuhan tertinggi terjadi pada tahun 2013 yaitu sebanyak 113 dokumen $(14,71 \%)$. Posisi kedua terjadi pada tahun 2014 yaitu sebanyak 104 publikasi $(13,54 \%)$ diikuti tahun 201 sebanyak 88 dokumen $(11,46 \%)$, dan tahun 2011 sebanyak 84 dokumen $(10,94 \%)$.

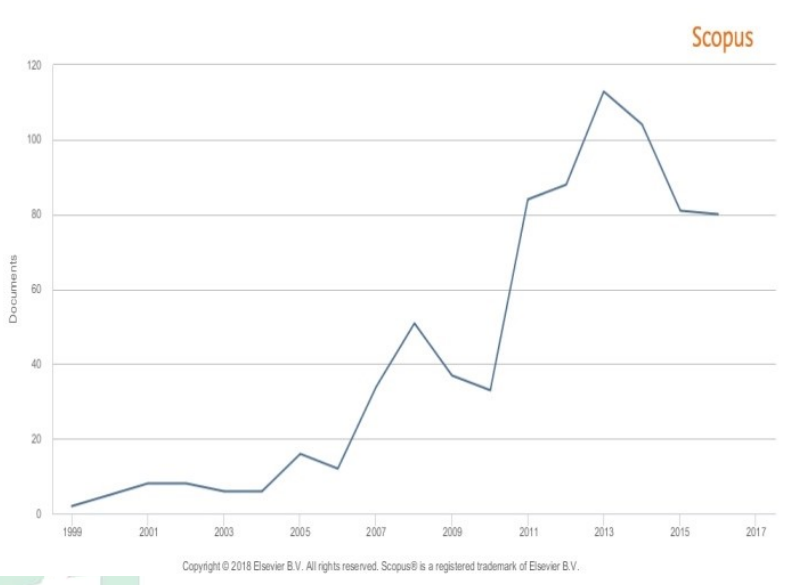

Gambar 2. Jumlah publikasi ilmiah ilmu dan teknologi pangan berdasarkan tahun

\section{b. Pertumbuhan Jurnal Inti (Core Journal) dalam Publikasi Ilmiah Ilmu dan Teknologi Pangan}

Dari hasil penelusuran dengan kata kunci food science and technology pada database Scopus diperoleh sebanyak 768 dokumen. Dari jumlah tersebut publikasi ilmiah ilmu dan teknologi pangan negaranegara ASEAN terbanyak dipublikasikan pada jurnal inti International Journal of Food Science and Technology yaitu sebanyak 240 publikasi. Selengkapnya 10 besar jurnal inti yang mempublikasikan publikasi ilmiah ilmu dan teknologi pangan dapat dilihat pada Tabel 2 berikut. 
Tabel 2. Jurnal inti dalam publikasi ilmiah ilmu dan teknologi pangan

\begin{tabular}{l|c}
\hline \multicolumn{1}{c|}{ Jurnal Inti } & Jumlah Dokumen \\
\hline $\begin{array}{l}\text { International Journal Of } \\
\text { Food Science And } \\
\text { Technology }\end{array}$ & 240 \\
\hline $\begin{array}{l}\text { International Food Research } \\
\text { Journal }\end{array}$ & 138 \\
\hline $\begin{array}{l}\text { Lwt Food Science And } \\
\text { Technology }\end{array}$ & 71 \\
\hline $\begin{array}{l}\text { Food Science And } \\
\text { Biotechnology }\end{array}$ & 67 \\
\hline $\begin{array}{l}\text { Food Science And } \\
\text { Technology Research }\end{array}$ & 23 \\
\hline $\begin{array}{l}\text { Philippine Journal Of } \\
\text { Science }\end{array}$ & 7 \\
\hline $\begin{array}{l}\text { Advances In Natural } \\
\text { Sciences Nanoscience And } \\
\text { Nanotechnology }\end{array}$ & \\
\hline $\begin{array}{l}\text { Food And Bioprocess } \\
\text { Technology }\end{array}$ & 6 \\
\hline $\begin{array}{l}\text { Asia Pacific Journal Of } \\
\text { Clinical Nutrition }\end{array}$ & 6 \\
\hline Food Security & 5 \\
\hline
\end{tabular}

Dari Tabel 2 dan Gambar 3 terlihat bahwa 10 jurnal inti yang terbanyak yang mempublikasikan publikasi ilmiah ilmu dan teknologi pangan adalah International Journal of Food Science And Technology sebanyak 240 publikasi, disusul International Food Research Journal 138 publikasi, Lwt Food Science And Technology 71 publikasi, Food Science And Biotechnology 67 publikasi dan Food Science and Technology Research 23 publikasi.

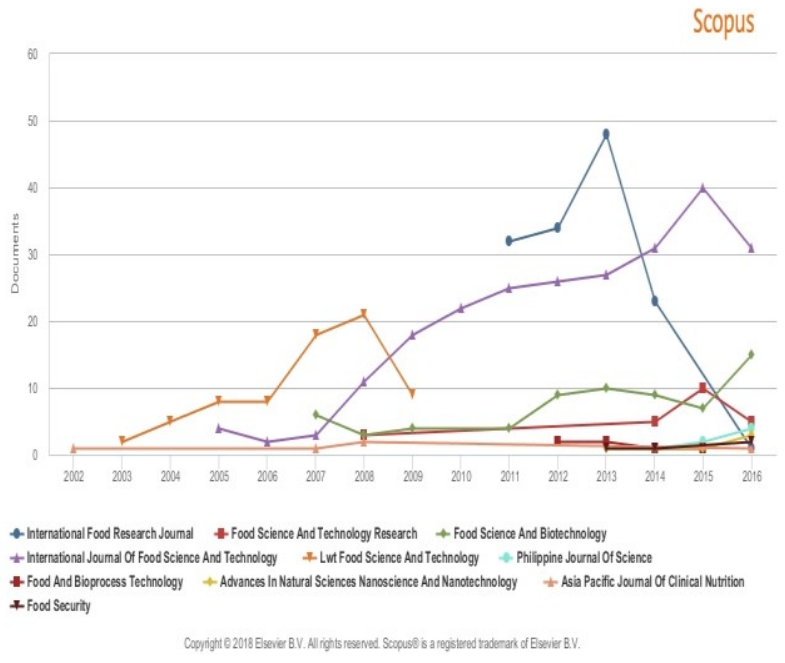

Gambar 3. Jurnal inti publikasi ilmiah ilmu dan teknologi pangan

\section{c. Jumlah Publikasi Ilmiah Negara- negara ASEAN Menurut Afiliasi/Lembaga}

Analisis data menunjukkan bahwa publikasi ilmiah ilmu dan teknologi pangan yang dihasilkan oleh negaranegara ASEAN terbanyak dihasilkan oleh Universiti Putra Malaysia. Disusul berturut turut Kasetsart University dan Prince of Songkla University. Selengkapnya jumlah publikasi ilmiah ilmu dan teknologi pangan yang dihasilkan oleh negara-negara ASEAN dapat dilihat pada Tabel 3 berikut. 
Tabel 3. Jumlah Publikasi Ilmiah Ilmu dan Teknologi Pangan Menurut Afiliasi/Lembaga

\begin{tabular}{l|c}
\hline \multicolumn{1}{c|}{ Lembaga/Afiliasi } & $\begin{array}{c}\text { Jumlah } \\
\text { Dokumen }\end{array}$ \\
\hline Universiti Putra Malaysia & 95 \\
\hline Kasetsart University & 69 \\
\hline Prince of Songkla University & 59 \\
\hline National University of Singapore & 47 \\
\hline Universiti Sains Malaysia & 39 \\
\hline Universiti Kebangsaan Malaysia & 39 \\
\hline Chulalongkorn University & 31 \\
\hline Chiang Mai University & 25 \\
\hline $\begin{array}{l}\text { King Mongkuts University of } \\
\text { Technology Thonburi }\end{array}$ & 21 \\
\hline $\begin{array}{l}\text { Asian Institute of Technology } \\
\text { Thailand }\end{array}$ & 21 \\
\hline
\end{tabular}

Dilihat dari Tabel 3 dan Gambar 4 menunjukkan bahwa dari 10 lembaga peringkat tertinggi penyumbang publikasi ilmiah ilmu dan teknologi pangan negaranegara ASEAN adalah Universiti Putra Malaysia sebanyak 95 publikasi.

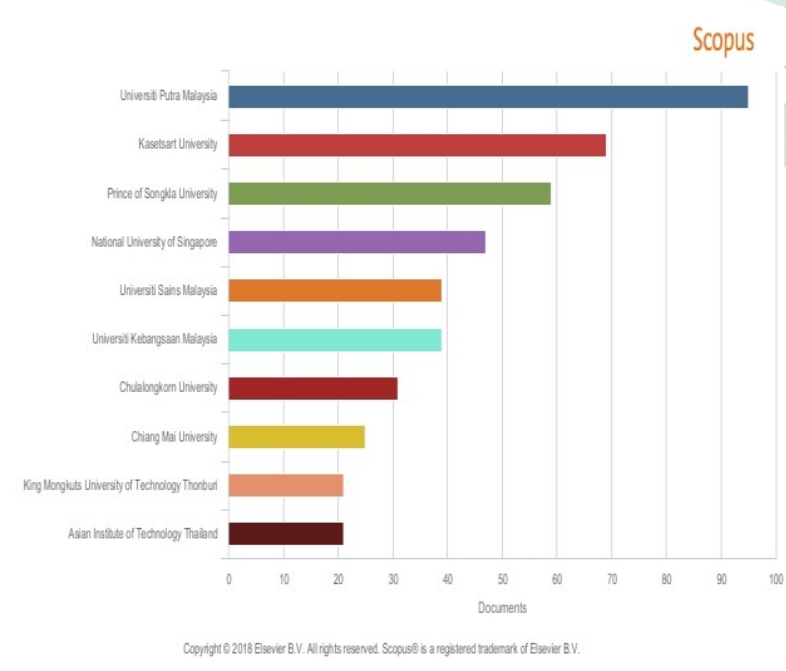

Gambar 4. Jumlah publikasi hasil penelitian bidang instrumentasi berdasarkan afiliasi/lembaga

\section{d. Produktivitas Peneliti}

Peneliti ilmu dan teknologi pangan negara-negara ASEAN yang paling produktif adalah Benjakul dari Prince of Songkla University, Department of Food Technology, Hatyai, Thailand dan disusul diurutan ke dua Prinyawiwatkul. Selengkapnya produktivitas peneliti negara-negara ASEAN dapat dilihat pada Tabel 4 . berikut.

Tabel 4. Produktivitas Peneliti Ilmu dan Teknologi Pangan Negara-negara ASEAN

\begin{tabular}{|l|c|}
\hline \multicolumn{1}{|c|}{ Peneliti } & $\begin{array}{c}\text { Jumlah } \\
\text { Dokumen }\end{array}$ \\
\hline \hline Benjakul, S. & 33 \\
\hline Prinyawiwatkul, W. & 14 \\
\hline Visessanguan, W. & 12 \\
\hline Noomhorm, A. & 11 \\
\hline Therdthai, N. & 11 \\
\hline Devahastin, S. & 10 \\
\hline Jangchud, A. & 10 \\
\hline Jangchud, K. & 10 \\
\hline Liu, S.Q. & 10 \\
\hline Mujumdar, A.S. & 10 \\
\hline
\end{tabular}

Dari Tabel 4 dan Gambar 5 menunjukkan bahwa peneliti paling produktif ilmu dan teknlogi pangan dari negara-negara ASEAN adalah dari negara Thailand diantaranya Benjakul, S., Benjakul, S., Noomhorm, A, Therdthai, N., Devahastin, S.. Adapun penulis terproduktif kedua adalah Singapore yaitu Liu, Shao Quan dari National 
University of Singapore, Department of Chemistry, Singapore City, Singapore.

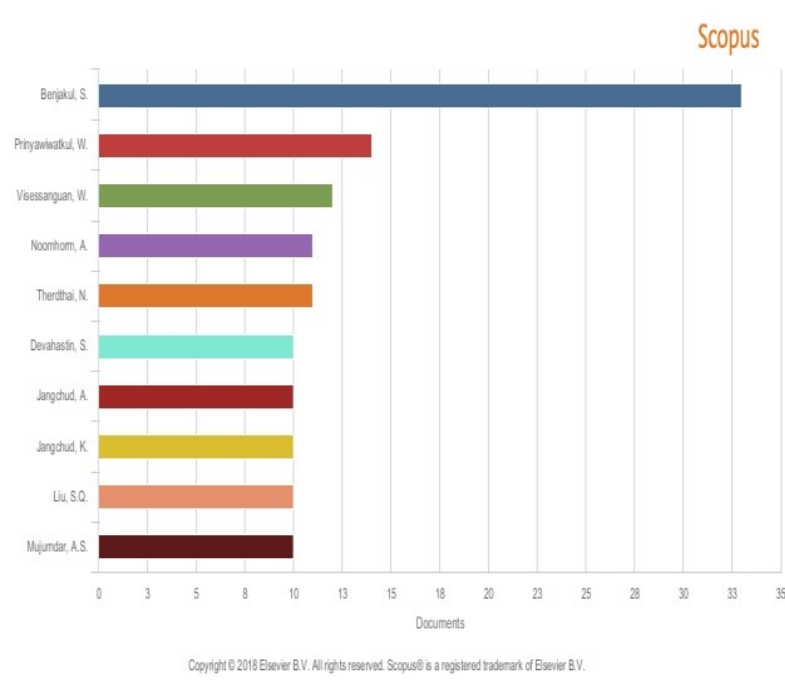

Gambar 5. Produktivitas penulis

\section{e. Jumlah Publikasi Ilmiah Ilmu dan Teknologi Pangan Negara ASEAN}

Dari hasil pengelompokan berdasarkan negara menunjukkan bahwa Thailand merupakan negara ASEAN teritinggi penyumbang publikasi ilmiah ilmu dan teknologi pangan tertinggi. Disusul Malaysia, Singapore dan Indonesia di urutan yang ke empat.

Tabel 5. Jumlah Publikasi Ilmiah Ilmu dan Teknologi Pangan Negara ASEAN

\begin{tabular}{|l|c|}
\hline \multicolumn{1}{|c|}{ Negara } & $\begin{array}{c}\text { Jumlah } \\
\text { Dokumen }\end{array}$ \\
\hline \hline Thailand & 310 \\
\hline Malaysia & 240 \\
\hline Singapore & 73 \\
\hline Indonesia & 63 \\
\hline Philippines & 59 \\
\hline Viet Nam & 42 \\
\hline
\end{tabular}

\begin{tabular}{|l|c|}
\hline \multicolumn{1}{|c|}{ Negara } & $\begin{array}{c}\text { Jumlah } \\
\text { Dokumen }\end{array}$ \\
\hline Cambodia & 4 \\
\hline Brunei Darussalam & 2 \\
\hline Laos & $\underline{2}$ \\
\hline Myanmar & $\underline{1}$ \\
\hline
\end{tabular}

Dari Tabel 5 dan Gambar 6 menunjukkan bahwa negara yang paling produktif mempublikasikan publikasi ilmiah ilmu dan teknologi pangan adalah Thailand sebanyak 310 publikasi. Disusul diurutan ke dua yaitu Malysia sebanyak 240 publikasi, kemudian diikuti Singapura sebanyak 73 publikasi dan Indonesia sebanyak 63 publikasi. Dari peta densiti menunjukkan bahwa Thailand merupakan negara tertinggi penyumbang publikasi ilmiah ilmu dan teknologi pangan, hal itu terlihat dari peta dengan lingkaran warna merah yang paling besar dan tebal. Dari peta juga terlihat bahwa Malysia merupakan urutan kedua terbanyak publikasi ilmiah ilmu dan teknologi pangan. 


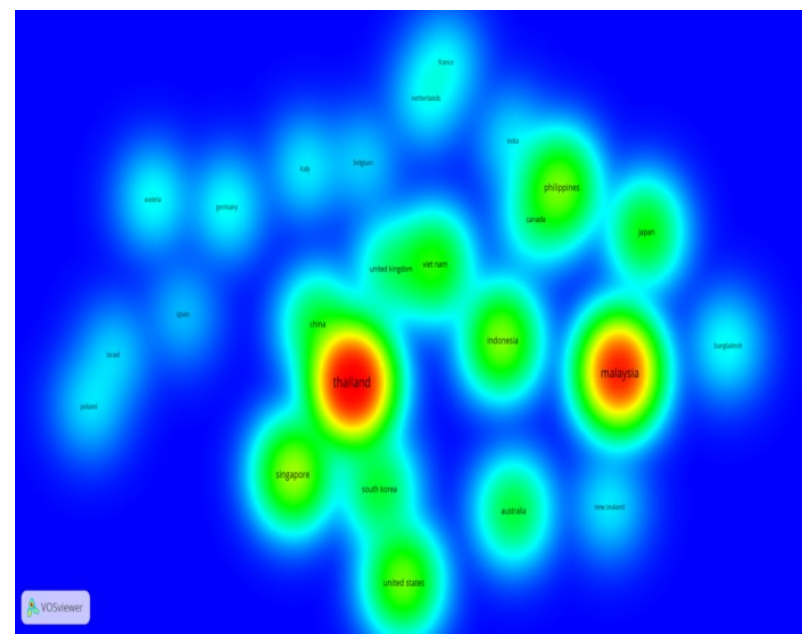

Gambar 6. Peta densiti publikasi ilmiah ilmu dan teknologi pangan Negara ASEAN

\section{f. Jumlah Publikasi Ilmiah Ilmu dan Teknologi Pangan Negara-negara ASEAN Berdasarkan Subjek}

Publikasi ilmiah ilmu dan teknologi pangan negara-negara ASEAN menunjukkan bahwa subjek yang terbanyak adalah Agricultural and Biological Sciences, disusul subjek Engineering, Biochemistry, Genetics and Molecular Biology. Selengkapnya subjek publikasi ilmiah ilmu dan teknologi pangan negara-negara ASEAN dapat dilihat pada Tabel 1. berikut.

Tabel 6. Jumlah Publikasi Ilmiah Ilmu dan Teknologi Pangan Negara-negara ASEAN

\begin{tabular}{|l|c|}
\hline \multicolumn{1}{|c|}{ Subjek } & $\begin{array}{c}\text { Jumlah } \\
\text { Dokumen }\end{array}$ \\
\hline $\begin{array}{l}\text { Agricultural and Biological } \\
\text { Sciences }\end{array}$ & 620 \\
\hline Engineering & 318 \\
\hline $\begin{array}{l}\text { Biochemistry, Genetics and } \\
\text { Molecular Biology }\end{array}$ & 112 \\
\hline $\begin{array}{l}\text { Immunology and } \\
\text { Microbiology }\end{array}$ & 74 \\
\hline
\end{tabular}

\begin{tabular}{|c|c|}
\hline Subjek & $\begin{array}{l}\text { Jumlah } \\
\text { Dokumen }\end{array}$ \\
\hline Chemical Engineering & 50 \\
\hline Environmental Science & 34 \\
\hline Social Sciences & 32 \\
\hline $\begin{array}{l}\text { Business, Management and } \\
\text { Accounting }\end{array}$ & 28 \\
\hline Chemistry & 22 \\
\hline Medicine & 22 \\
\hline Computer Science & 20 \\
\hline Materials Science & 17 \\
\hline Nursing & 10 \\
\hline Physics and Astronomy & 10 \\
\hline Energy & 9 \\
\hline $\begin{array}{l}\text { Pharmacology, Toxicology } \\
\text { and Pharmaceutics }\end{array}$ & 8 \\
\hline Mathematics & 7 \\
\hline Earth and Planetary Sciences & 5 \\
\hline $\begin{array}{l}\text { Economics, Econometrics } \\
\text { and Finance }\end{array}$ & 5 \\
\hline Arts and Humanities & 4 \\
\hline Multidisciplinary & 4 \\
\hline Decision Sciences & 3 \\
\hline Veterinary & 2 \\
\hline Neuroscience & 1 \\
\hline Total & 768 \\
\hline
\end{tabular}

Berdasarkan Tabel 6 dan Gambar 7 menunjukkan bahwa subjek yang terbanyak publikasi ilmiah negara-negara ASEAN yang terbanyak adalah Agricultural and Biological Sciences sebanyak 620 dokumen $(80,7 \%)$, disusul Engineering sebanyak 318 (41,4\%), 
Biochemistry, Genetics and Molecular Biology sebanyak 112 dokumen (14,6\%), Immunology and Microbiology 74 dokumen $(9,6 \%)$.

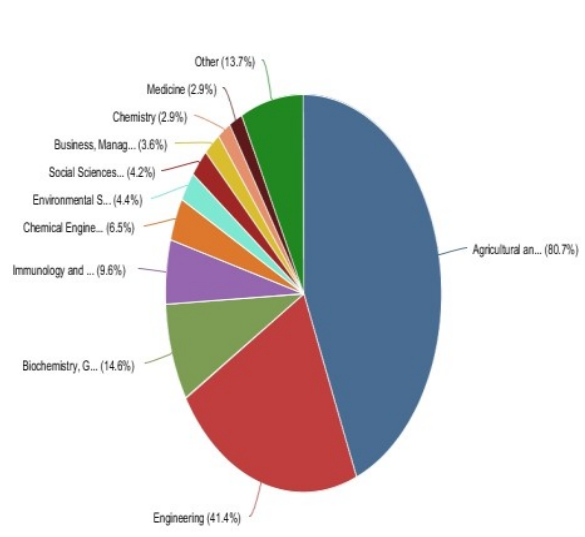

Gambar 7. Jumlah publikasi ilmiah ilmu dan teknologi pangan Negara ASEAN

g. Pertumbuhan Publikasi Ilmiah Ilmu dan teknologi Pangan Berdasarkan Tipe Dokumen

Dari hasil penelusuran menunjukkan bahwa publikasi ilmiah ilmu dan teknologi pangan negara-negara ASEAN yang terbanyak adalah dalam bentuk artikel, disusul review, conference paper dan book chapter. Selengkapnya publikasi ilmiah ilmu dan teknologi pangan negaranegara ASEAN berdasarkan tipe dokumen dapat dilihat pada Tabel 7 . Berikut.

Tabel 7. Jumlah publikasi ilmiah ilmu dan teknologi pangan berdasarkan tipe dokumen

\begin{tabular}{|c|c|}
\hline Tipe Dokumen & Jumlah Dokumen \\
\hline Article & 646 \\
\hline Review & 50 \\
\hline Conference Paper & 36 \\
\hline Book Chapter & 16 \\
\hline
\end{tabular}

\begin{tabular}{|c|c|}
\hline Tipe Dokumen & Jumlah Dokumen \\
\hline Short Survey & 8 \\
\hline Book & 6 \\
\hline Editorial & 4 \\
\hline Erratum & 1 \\
\hline Note & 1 \\
\hline Total & 768 \\
\hline
\end{tabular}

Dilihat dari Tabel 7 dan Gambar 8 menunjukkan bahwa publikasi ilmiah ilmu dan teknologi pangan negara-negara ASEAN yang tertinggi adalah dalam bentuk artikel yaitu sebanyak $646(84,1 \%)$, disusul review sebanyak 50 publikasi $(6,5 \%)$, conference paper 36 publikasi $(4,7 \%)$, dan book chapter $16(2,1 \%)$.

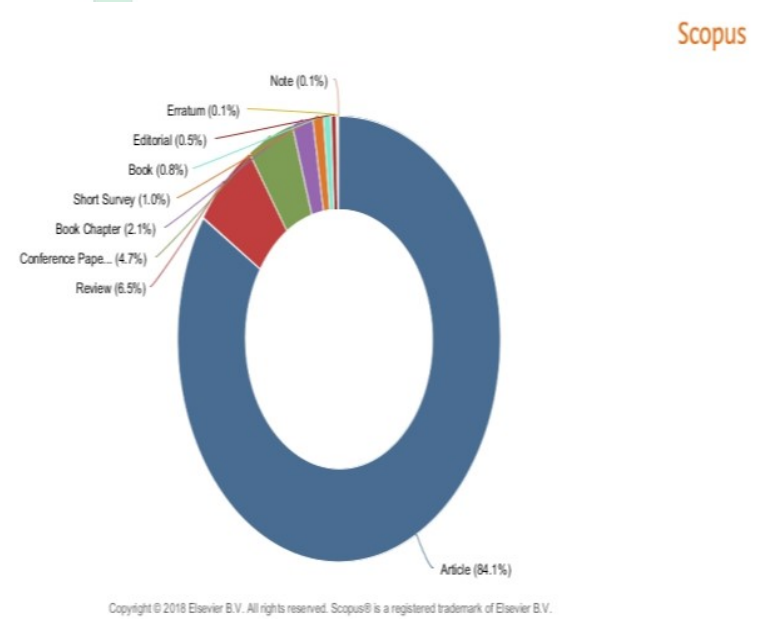

Gambar 8. Pertumbuhan publikasi ilmiah ilmu dan teknologi pangan berdasarkan jenis dokumen

\section{h. Peta Pertumbuhan Ilmu dan Teknologi Pangan Berdasarkan Kata Kunci}

Hasil penelusuran publikasi ilmiah ilmu dan teknologi pangan negara-negara ASEAN pada database scopus diperoleh 
sebanyak 768 dokumen kemudian. Hasil penelusuran kemudian diekspor ke format CSV, diinput dan dianalisis dengan VOSViewer sehingga diperolehhasil berupa visualisasi network dan densiti peta co-word pertumbuhan publikasi ilmiah ilmu dan teknologi pangan yang dihasilkan oleh negaranegara ASEAN.

Pemetaan bibliometrik merupakan metode visualisasi sebuah bidang ilmu yang dilakukan dengan menciptakan peta lanskap yang dapat menampilkan topik dari ilmu pengetahuan (Royani, et al., 2013). Hasil visualisasi network peta coword ilmu dan teknologi pangan seperti terlihat pada gambar 8 terbagi menjadi 6 kluster. Kluster 1 warna terdiri dari 70 topik di antaranya adalah amino acids, amilose content, ananas comosus, anti oxidative activity, calcium, carbohydrates, collagen, cooking, cucumis, edible coating, emulsification, enzimatic hydrolysis, enzyme activity, enzyme inhibitton, enzymes, fish, food additives, food storage, freezing, functional properties, gelatin, gels, grain, hydrolysis, lipid oxidation, lipid, meats, moisture, oil and fats, oilseeds, oxidation, particle size, pectin, peptides, pineaple, polyphenol oxidase, polysaccharides, protein hydrolisate, proteins, resistan starch, rice bran protein, rice brans, rice flour, solanum tuberosum, solubiliy, starch, tilapia, dan triticum aestivum. Kluster 2 warna hijau terdiri dari 62 topik yaitu food, food and drug administration, food industry, food packaging, food processing, food quality, food safety, food security, food supply, food technology, geneticaly modified food, nutrition, Oryza sativa, dan Zea mays. Kluster 3 warna biru terdiri dari 55 topik yaitu agricultural product, amines, beverages, chitin, chitosan, curcuma longa, dairy product, decapoda, encapsulation, food microbilogy, functional food, lactic acid, lactic acid bacteria, lactobacillus plantarum, probiotic, shellfish, sugars, dan thermal processing food. Kluster 4 berwarna kuning terdiri dari 55 topik yaitu bioactive compound, blanching, carica papaya, carotenoids, citrus maxima, colour, curing, daucus carota, dryers, drying, food industry, food preservation, foood product, fruits, glycerol, glicine max, ipomoea batatas, manihot esculenta, palm oil, papaya, sugar, sweet potato, tectures, dan vegetable. Kluster 5 warna ungu terdiri dari 42 topik yaitu acetone, algae, anthocyanin, antioxidant activities, antioxidan capacity, essential oil, ethanol, flavonoids, psidium guajava, sensory properties, dan theobroma cacao. Kluster 6 warna biru muda terdiri dari 35 topik yaitu aldehydes, aroma compounds, citrus, durio zibethinus, fermentation, flavour, freeze drying, fruit juices, glucose, pasteurization, sacharomyces cereviceae, vitamins, volatil compound, volatil organic cmpound, wine dan yeast.

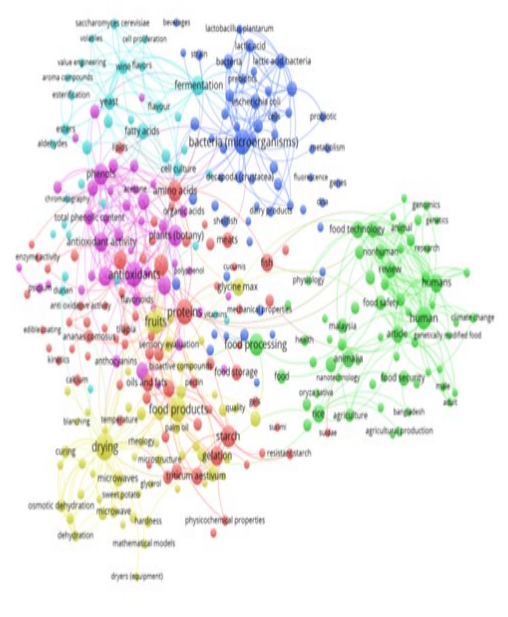

Gambar 9. Peta visualisasi network pertumbuhan ilmu dan teknologi pangan

Gambar 9 menunjukkan cluster density view yang merupakan item atau label yang ditandai dengan sama dengan item yang terlihat. Setiap titik item memiliki warna yang tergantung pada 
kepadatan item pada saat itu. Melalui lembar kerja ini, kita dapat menafsirkan keywords yang paling banyak digunakan dalam suatu publikasi. Dari gambar 10 terlihat bahwa kluster yang berwarna merah menunjukkan bahwa hubungannya semakin rapat dan semakin hijau warnanya hubungannya semakin jarang.

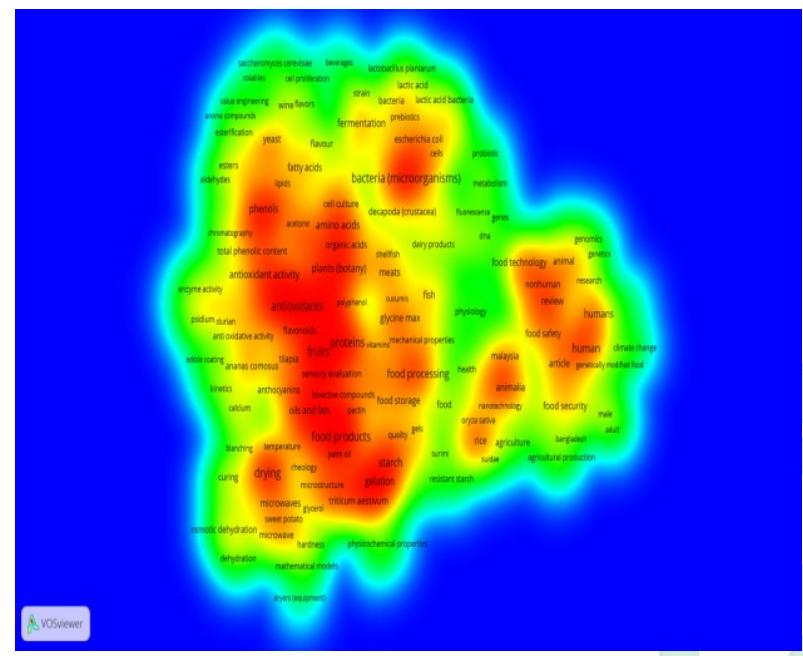

Gambar 10. Peta visualisasi densiti pertumbuhan ilmu dan teknologi pangan

\section{KESIMPULAN}

Berdasarkan hasil dan pembahasan diatas dapat disimpulkan bahwa pertumbuhan publikasi ilmiah ilmu dan teknologi pangan negara-negara ASEAN menunjukkan bahwa selama periode tahun 1996-2016 mengalami kenaikan dan pertumbuhan tertinggi terjadi pada tahun 2013 yaitu sebanyak 113 dokumen (14,71\%). Publikasi ilmiah ilmu dan teknologi pangan negara-negara ASEAN terbanyak dipublikasikan pada jurnal inti International Journal Of Food Science And Technology yaitu sebanyak 240 publikasi. Lembaga penyumbang publikasi ilmiah ilmu dan teknologi pangan negara-negara
ASEAN tertinggi adalah Universiti Putra Malaysia sebanyak 95 publikasi. Peneliti paling produktif ilmu dan teknlogi pangan dari negara-negara ASEAN adalah dari negara Thailand diantaranya Benjakul, S., Benjakul, S., Noomhorm, A, Therdthai, N., Devahastin, S. Negara yang paling produktif mempublikasikan publikasi ilmiah ilmu dan teknologi pangan adalah Thailand sebanyak 310 publikasi. Subjek yang terbanyak publikasi ilmiah negara-negara ASEAN yang terbanyak adalah Agricultural and Biological Sciences sebanyak 620 dokumen (80,7\%), disusul Engineering sebanyak 318 (41,4\%), Biochemistry, Genetics and Molecular Biology sebanyak 112 dokumen (14,6\%), Immunology and Microbiology 74 dokumen (9,6\%) dan tertinggi dalam bentuk artikel. Melalui visualisai network menunjukkan bahwa hubungan antartopik diperlihatkan dengan garis antardeskriptor pada masing-masing bidang mengelompok menjadi 7 kluster. Adapun visualisasi densiti menunjukkan bahwa warna semikin merah hubungannya semakin rapat dan semakin hijau warnanya hubungannya semakin jarang.

\section{DAFTAR PUSTAKA}

Haustein, S., et al. (2011). Reasons for and developments in international scientific collaboration: does an Asia-Pacific research area exist from a bibliometric point of view? Scientometrics, 86, 727-746.

Kumar, S., et al. (2014). International research collaborations of ASEAN Nations in economics, 1979-2010. Scientometrics, 101, 847-867. 
Lakitan, B., dkk. (2012). Scientific productivity and the collaboration intensity of Indonesian universities and public R\&D institutions: Are there dependencies on collaborative R\&D with foreign institutions?. Technology in Society, 34, 227238.

Nuryudi. (2016). Analisis Bibliometrika Islam: Studi Kasus Dokumentasi Publikasi Ilmiah di UIN Syarif Hidayatullah Jakarta. AlMaktabah: Jurnal Komunikasi dan Informasi Perpustakaan, 15, 1, 4155.

Payumo, J. G., dan Sutton, T. C. (2015). A bibliometric assessment of ASEAN collaboration in plant biotechnology. Scientometrics, 103, 3, 1043-1059.

Sombatsompop, N., et al. (2011). Research productivity and impact of ASEAN countries and universities in the field of energy and fuel. Malaysian Journal of Library \& Information Science, 16, 1, 35-46.

U1 Hassan, S., et al. (2012). A bibliometric study of research activity in ASEAN related to the EU in FP7 priority areas. Scientometrics, 91 . 